\title{
Perlindungan Hukum Bagi Pemenang Lelang Apabila Obyek Lelang Disita Dalam Perkara Pidana
}

\author{
Desminurva Festia Amalia \\ Magister Kenotariatan Fakultas Hukum Universitas Airlangga \\ Email : desminurvafest@gmail.com
}

\begin{abstract}
Auction as a sale-purchase agreement, so the regulation by $B W$ also valid in an auction. Elements of auction are same in definition of sale-purchase, there are, the subject law as seller and buyer, the agreement between seller and buyer about goods and price, the rights and obligations which arising of parties the seller and buyer. The essence of auction and trading is the goods and the payment of price. Auction is trading contracts, the legal relation in auction is between the seller, bidder buyers through official auction.

In its implementation, sometimes there are still many problems happened, one of them is when goods were auctioned off, especially an executed guarantee and put civil seized, turns out that caught with criminal issue faced by the owner, while bidding has been implemented and has been choosen a winner of auction to have paid the price. Especially if it to do execution/seized. Even in article 39 paragraph (2) KUHAP said that civil execution of the goods can also criminal execution. So the thesis aims to understand legal certainty of the auction and what kind of legal efforts that can do by the auctions winner who feel lose out if objects auction seized in criminal cases.
\end{abstract}

Keywords: Auctions, Civil Executed, Criminal Executed.

\begin{abstract}
Abstrak
Lelang adalah sebagai suatu perjanjian jual beli, maka ketentuan jual beli sebagaimana diatur oleh BW juga berlaku dalam lelang. Lelang mengandung unsur-unsur yang tercantum dalam definisi jual beli adanya subjek hukum, yaitu penjual dan pembeli, adanya kesepakatan antara penjual dan pembeli tentang barang dan harga, adanya hak dan kewajiban yang timbul diantara pihak penjual dan pembeli. Esensi dari lelang dan jual beli adalah penyerahan barang dan pembayaran harga. Lelang adalah perjanjian jual beli, hubungan hukum yang terdapat di lelang adalah hubungan hukum jual beli antara penjual lelang dengan pembeli lelang dengan perantaraan pejabat lelang.

Dalam pelaksanaannya, terkadang masih banyak masalah yang terjadi, salah satunya apabila barang yang dilelang, terutama barang jaminan yang dieksekusi dan diletakkan sita perdata, ternyata tersangkut paut dengan masalah pidana yang dihadapi oleh pemiliknya, padahal lelang telah dilaksanakan dan telah ditunjuk pemenang lelangnya hingga


Fairness and Justice: Jurnal Ilmiah Ilmu Hukum

p-ISSN: 1858-0106 e-ISSN: 2502-3926

Volume 17 Nomor 1 Mei 2019, Hlm 18-35

http://jurnal.unmuhjember.ac.id/index.php/FA

telah membayar harga lelang yang telah diputuskan. Apalagi jika barang tersebut harus dilakukan penyitaan. Bahkan di dalam Pasal 39 ayat (2) KUHAP menyebutkan bahwa barang yang disita perdata dapat juga disita pidana. Sehingga, tesis ini bertujuan untuk mengetahui kepastian hukum terhadap proses lelang dan upaya hukum apa yang dapat dilakukan oleh pemenang lelang yang dirugikan apabila obyek lelang disita dalam perkara pidana.

Kata Kunci: Lelang, Sita Perdata, Sita Pidana.

\section{Pendahuluan}

Lelang adalah sebagai suatu perjanjian jual beli, maka ketentuan jual beli sebagaimana diatur oleh BW juga berlaku dalam lelang. Lelang mengandung unsur-unsur yang tercantum dalam definisi jual beli adanya subjek hukum, yaitu penjual dan pembeli, adanya kesepakatan antara penjual dan pembeli tentang barang dan harga, adanya hak dan kewajiban yang timbul diantara pihak penjual dan pembeli. Esensi dari lelang dan jual beli adalah penyerahan barang dan pembayaran harga. Lelang adalah perjanjian jual beli, hubungan hukum yang terdapat di lelang adalah hubungan hukum jual beli antara penjual lelang dengan pembeli lelang dengan perantaraan pejabat lelang. ${ }^{1}$

Dalam pelaksanaannya, terkadang masih banyak masalah yang terjadi, salah satunya apabila barang yang dilelang, terutama barang jaminan yang dieksekusi dan diletakkan sita perdata, ternyata tersangkut paut dengan masalah pidana yang dihadapi oleh pemiliknya, padahal lelang telah dilaksanakan dan telah ditunjuk pemenang lelangnya hingga telah membayar harga lelang yang telah diputuskan. Apalagi jika barang tersebut harus dilakukan penyitaan. Sita pidana atas sita perdata ini ditegaskan pula dalam Pasal 39 ayat (2) KUHAP.

Undang-undang menetapkan penyitaan pidana memiliki urgensi publik yang lebih tinggi dibanding dengan kepentingan individu dalam

${ }^{1}$ Purnama Tiora Siantura. 2013. Perlindungan Hukum Terhadap Pembeli Barang Jaminan Tidak Bergerak Melalui Lelang. Bandung: CV. Mandar Maju. Hlm. 96 Pengelola: Program Studi Ilmu Hukum Universitas Muhammadiyah Jember 
Fairness and Justice: Jurnal Ilmiah Ilmu Hukum

p-ISSN: 1858-0106 e-ISSN: 2502-3926

Volume 17 Nomor 1 Mei 2019, Hlm 18-35

http://jurnal.unmuhjember.ac.id/index.php/FA

bidang perdata. Karena itu, kepentingan seseorang sebagai pemohon dan pemegang sita revindikasi, sita jaminan atau sita eksekusi, sita umum dalam pailit harus dikesampingkan demi melindungi kepentingan umum, dengan jalan menyita barang itu dalam perkara pidana, apabila barang yang bersangkutan memenuhi kategori yang dideskripsikan Pasal 39 ayat (1) KUHAP. ${ }^{2}$ Memang, sita dalam KUHAP tidak lain hanya dimaksudkan untuk tujuan pembuktian perkara pidana yang sedang disidik atau dituntut ataupun disidangkan di pengadilan. Artinya, barang sitaan tersebut tidak boleh digunakan bebas oleh pemiliknya dan juga tidak boleh diperalihkan misalnya jual beli, sewa menyewa, hibah dan sebagainya, sampai perkara pidana itu selesai dan terhadapnya ada putusan hukum yang pasti. Kemudian di dalam putusan pidana tersebut akan di tetapkan status hukum dari barang yang disita, apakah akan dimusnahkan atau disimpan menjadi milik negara, atau dikembalikan kepada yang paling berhak. Jadi, di dalam acara pidana, sita tersebut dilakukan agar jangan sampai berubah bentuk/wujud sehingga pembuktian perkara pidana menjadi tidak tercapai. ${ }^{3}$ Jika hakim sudah memutuskan status barang sita, misalnya dimusnahkan atau disimpan menjadi milik negara, maka tidak dapat lagi dimiliki oleh siapapun.

Hal ini jelas akan merugikan hak dari pihak pembeli yang telah memiliki itikad baik untuk membeli dan membayar barang yang telah diputuskan untuk menjadi miliknya. Namun nyatanya, KUHAP telah menjelaskan bahwa sita pidana terhadap sita perdata tetap harus dilakukan untuk kepentingan penyidikan, penuntutan dan pengadilan. Pemenang lelang pun juga tidak dapat mengajukan gugatan terhadap sita pidana tersebut. Juga apakah lelang tersebut sah karena pelaksanaannya

2 M. Yahya Harahap. 2009. Hukum Acara Perdata tentang Gugatan, Persidangan, Penyitaan, Pembuktian dan Putusan Pengadilan. Jakarta: Sinar Grafika. Hlm. 324

${ }^{3}$ Nikolas Simanjuntak. 2009. Acara Pidana Indonesia Dalam Sirkus Hukum. Bogor: Ghalia Indonesia. Hlm. 98

Pengelola: Program Studi Ilmu Hukum Universitas Muhammadiyah Jember

Penerbit: Universitas Muhammadiyah Jember 
Fairness and Justice: Jurnal Ilmiah Ilmu Hukum

p-ISSN: 1858-0106 e-ISSN: 2502-3926

Volume 17 Nomor 1 Mei 2019, Hlm 18-35

http://jurnal.unmuhjember.ac.id/index.php/FA

telah dilakukan hingga telah menunjuk pemenang dan pembayaran harga lelang. Maka disinilah hukum di perlukan untuk melindungi hak-hak dari pemenang lelang. Namun pada kenyataannya, baik Vendu Reglement maupun PMK No. 27/PMK.06/2016 belum mampu memberikan solusi atau jawaban terhadap permasalahan tersebut.

\section{Metode Penelitian}

Untuk kebenaran atas suatu karya ilmiah maka di dalam penelitian harus menggunakan sebuah metodologi yang tepat, karena hal tersebut merupakan pedoman yang menentukan akan kualitas hasil yang didapatkan atas suatu penelitian. Berdasar atas pendapat di atas, penelitian tentang perlindungan hukum keterwakilan perempuan dalam pemilihan umum legislatif dalam tata hukum di Indonesia merupakan penelitian yuridis normatif. Penelitian yuridis normatif merupakan penelitian kepustakaan yang menggunakan sumber bahan hukum kepustakaan. ${ }^{4}$

\section{Hasil dan Pembahasan}

\subsection{Kepastian Hukum Penjualan Lelang}

\subsubsection{Fungsi dan Prosedur Lelang}

Secara yuridis, pengertian lelang sebagai penjualan di muka umum terdapat dalam Peraturan Lelang/Vendureglement (Peraturan Penjualan di Muka Umum di Indonesia) Ordonansi 28 Pebruari 1908 L.N. 08-189 mulai berlaku 1 April 1908, yaitu di dalam Pasal 1. Pengertian Lelang juga diatur dalam Pasal 1 angka 1 Peraturan Menteri Keuangan Nomor 93/PMK.06/2010 sebagaimana diubah dengan Peraturan Menteri

\footnotetext{
${ }^{4}$ Sidi Alkahfi Setiawan. 2013. Perlindungan Hukum Pekerja Pemegang Saham Di PT Bank Central Asia Tbk. Fakultas Hukum Universitas Jember. Jember. hlm. 18 Pengelola: Program Studi Ilmu Hukum Universitas Muhammadiyah Jember Penerbit: Universitas Muhammadiyah Jember
} 
Fairness and Justice: Jurnal Ilmiah Ilmu Hukum

p-ISSN: 1858-0106 e-ISSN: 2502-3926

Volume 17 Nomor 1 Mei 2019, HIm 18-35

http://jurnal.unmuhjember.ac.id/index.php/FA

Keuangan Nomor 106/PMK.06/2013 sebagaimana diubah dengan Peraturan Menteri Keuangan Nomor 27/PMK.06/2016 tentang Petunjuk Pelaksanaan Lelang (yang selanjutnya disebut PMK No. 27/PMK.06/2016).

Sebagai sarana penjualan barang secara terbuka, pranata lelang memiiki tiga fungsi sekaligus, yaitu Fungsi Privat; Fungsi Publik; dan Fungsi Budgeter. Selanjutnya mengenai Prosedur Lelang yang merupakan rangkaian perbuatan-perbuatan yang dilakukan sebelum lelang dilaksanakan disebut prosedur persiapan lelang/pra lelang, saat lelang dilaksanakan dan setelah lelang dilaksanakan, prosedur lelang dapat dibagi menjadi 3 (tiga) tahap yaitu: ${ }^{5}$

1. Tahap Persiapan Lelang

Menyangkut mulai dari permohonan lelang, penentuan tempat dan waktu lelang, penentuan syarat lelang, pelaksanaan pengumuman, melakukan permintaan surat keterangan tanah dan penyetoran uang jaminan.

\section{Tahap Pelaksanaan Lelang}

Menyangkut mengenai penentuan peserta lelang, penyerahan nilai limit, pelaksanaan penawaran lelang, dan penunjukan pembeli.

3. Tahap Pasca Lelang

Menyangkut pembayaran harga lelang penyetoran hasil lelang dan pembuatan risalah lelang pada tahap pelaksanaan lelang.

\subsubsection{Peralihan Kepemilikan Dalam Lelang}

Dalam lelang, yang diserahkan penjual kepada pembeli lelang ialah pemindahan hak kebendaan baik secara fisik dan nyata melalui penyerahan nyata (feitelijke levering) maupun secara yuridis (juridische

\footnotetext{
${ }^{5}$ Purnama Tioria Sianturi. Op.Cit. Hlm 82

Pengelola: Program Studi Ilmu Hukum Universitas Muhammadiyah Jember

Penerbit: Universitas Muhammadiyah Jember
} 
Fairness and Justice: Jurnal Ilmiah Ilmu Hukum

p-ISSN: 1858-0106 e-ISSN: 2502-3926

Volume 17 Nomor 1 Mei 2019, Hlm 18-35

http://jurnal.unmuhjember.ac.id/index.php/FA

levering), dengan kata lain hal yang dialihkan penjual kepada pembeli: Barang objek jual beli (property); dan Hak kebendaan yang melekat pada barang itu. ${ }^{6}$

Dengan telah dibuatnya berita acara lelang atau risalah lelang oleh pejabat dari Kantor Lelang, maka pada saat itu telah terjadi pemindahan hak atas tanah dari pemegang haknya semula sebagai penjual lelang kepada pihak lain sebagai pembeli lelang. Namun pemindahan hak tersebut hanyalah diketahui oleh kedua belah pihak, pihak ketiga tidak mengetahui tentang adanya lelang tersebut. Agar pihak ketiga mengetahuinya, maka lelang tersebut harus didaftarkan ke Kantor Pertanahan Kabupaten/Kota setempat karena pendaftaran tanah mempunyai sifat terbuka. Dengan pendaftaran pemindahan hak ke Kantor Pertanahan Kabupaten/Kota, maka terpenuhilah asas publisitas dalam pendaftaran tanah, yaitu setiap orang dapat mengetahui data fisik berupa letak, ukuran, batas-batas tanah, dan data yuridis berupa subjek hak, status hak dan pemindahan hak atas tanah yang bersangkutan ke Kantor Pertanahan Kabupaten/Kota. ${ }^{7}$

\subsubsection{Kepastian Hukum Terhadap Pembeli Lelang Yang Beritikad Baik Atas Objek Lelang Yang Disita Pidana}

Ukuran itikad baik seorang pembeli lelang, tidak diatur secara tegas dalam hukum positif, tetapi lebih tercermin dalam berbagai putusan hakim. Seperti dalam Putusan Mahkamah Agung RI tanggal 28 Agustus 1967 Reg. No. 821/K/Sip/1974, menyatakan bahwa pembeli yang membeli suatu barang melalui pelelangan umum oleh Kantor Lelang Negara adalah sebagai pembeli yang beritikad baik dan harus dilindungi oleh undang-undang. Hakim lebih menekankan ukuran itikad baik dalam

\footnotetext{
${ }^{6}$ Ibid.

${ }^{7}$ Urip Santoso. 2015. Pendaftaran dan Peralihan Hak Atas Tanah. Jakarta: Prenadamedia Group. Hlm. 388 Pengelola: Program Studi Ilmu Hukum Universitas Muhammadiyah Jember Penerbit: Universitas Muhammadiyah Jember
} 
Fairness and Justice: Jurnal Ilmiah Ilmu Hukum

p-ISSN: 1858-0106 e-ISSN: 2502-3926

Volume 17 Nomor 1 Mei 2019, Hlm 18-35

http://jurnal.unmuhjember.ac.id/index.php/FA

dimensi objektif pada saat pelaksanaan kontrak, karena adanya kepatutan dan kerasionalan, pembeli membeli melalui pelelangan umum, yang berarti membeli dalam suatu penjualan yang diumumkan ke khalayak umum dan melalui penawaran umum yang terbuka bagi setiap orang. ${ }^{8}$

Dari abstraksi tersebut, pembeli lelang yang beritikad baik semata disebabkan alasan pembeli membeli barang sebagai penangkap lelang umum/membeli melalui lelang umum, pembeli membeli barang dalam proses lelang yang terjadi secara wajar, pembeli lelang secara hukum, pembeli melaksanakan semua ketentuan sehubungan dengan pelaksanaan lelang. Empat kualitas/ukuran itikad baik yang diberikan hakim dalam putusan-putusan peradilan terlihat hakekat pemikiran hakim lebih didasarkan pada tujuan hukum berupa kepastian hukum terhadap pembeli lelang. Hakim lebih memilih kepastian hukum atas pembeli lelang. ${ }^{9}$

Menurut Ridwan Khairandy dalam Purnama Tioria Sianturi, menyatakan bahwa itikad baik menyangkut dimensi yang pertama yaitu dimensi subjektif yang berarti itikad baik mengarah pada makna kejujuran dan dimensi kedua adalah dimensi objektif yang memaknai itikad baik mengenai kerasionalan, kepatutan atau keadilan. Itikad baik dalam konteks Pasal 1338 ayat (3) BW harus didasarkan pada kerasionalan dan kepatutan. Itikad baik pra kontrak tetap mengacu pada itikad baik yang bersifat subjektif, yang digantungkan pada kejujuran para pihak. Seorang pembeli lelang yang beritikad baik berhubungan dengan dimensi subjektif yang harus ada dalam pra kontrak/sebelum pelaksanaan lelang, adalah seorang yang membeli barang dengan kejujuran penuh kepercayaan bahwa si penjual benar-benar pemilik barang. Pembeli yang beritikad baik adalah orang yang memiliki kejujuran yang tidak

${ }^{8}$ Purnama Tioria Sianturi. Op.Cit. Hlm. 376

${ }^{9}$ Ibid.

Pengelola: Program Studi Ilmu Hukum Universitas Muhammadiyah Jember

Penerbit: Universitas Muhammadiyah Jember 
Fairness and Justice: Jurnal Ilmiah Ilmu Hukum

p-ISSN: 1858-0106 e-ISSN: 2502-3926

Volume 17 Nomor 1 Mei 2019, Hlm 18-35

http://jurnal.unmuhjember.ac.id/index.php/FA

mengetahui adanya cacat yang melekat pada barang yang dibelinya itu, artinya cacat mengenai asal-usulnya. Sedangkan pembeli lelang yang beritikad baik dengan dimensi kedua/dimensi objektif adalah dimensi yang memaknai itikad baik pembeli lelang mengenai kerasionalan, kepatutan atau keadilan. ${ }^{10}$

Kemudian mengenai kepastian hukum bagi pembeli lelang, berarti bahwa barang yang dibeli melalui lelang itu bebas dari tuntutan pihak ketiga, pembei lelang mempunyai hak penuh/hak absolut/hak kebendaan atas barang lelang seperti hak milik atau hak kebendaan lainnya yang dapat dipertahankan terhadap gugatan dari siapapun yang dibelinya melalui lelang. Kepastian hak pembeli lelang berarti perlindungan yang diberikan kepada pembeli lelang terhadap individu lain di masyarakat terutama pihak-pihak yang memiliki kepentingan atas objek lelang seperti debitor, pihak ketiga dan hakim melalui putusanputusannya. ${ }^{11}$

Namun kemudian jika obyek lelang tersebut dilakukan penyitaan secara pidana karena pemilik awalnya telah melakukan tindak pidana yang memungkinkan semua harta kekayaannya harus disita, padahal pembeli lelang telah ditetapkan sebagai pemenang dan sudah melakukan pembayaran atas harga yang telah ditetapkan, maka tidak dapat melakukan perlawanan karena terbentur dengan Pasal 39 ayat (2) KUHAP.

\subsection{Upaya Hukum Pembeli Lelang Atas Obyek Lelang Yang Disita Dalam Perkara Pidana}

\subsubsection{Praperadilan Dalam Sita Pidana}

${ }^{10}$ Ibid. Hlm. 378

${ }^{11} \mathrm{Ibid}$. Hlm. 416

Pengelola: Program Studi Ilmu Hukum Universitas Muhammadiyah Jember

Penerbit: Universitas Muhammadiyah Jember 
Fairness and Justice: Jurnal Ilmiah Ilmu Hukum

p-ISSN: 1858-0106 e-ISSN: 2502-3926

Volume 17 Nomor 1 Mei 2019, Hlm 18-35

http://jurnal.unmuhjember.ac.id/index.php/FA

Mengenai benda yang di sita dalam perkara perdata dapat pula di sita dalam perkara pidana, hal ini dapat dilihat dalam Pasal 39 ayat (2) KUHAP. Barang yang disebut dalam Pasal 39 ayat (1) KUHAP dapat disita pula dalam perkara pidana. Undang-undang menetapkan penyitaan pidana memiliki urgensi publik yang lebih tinggi dibanding dengan kepentingan individu dalam bidang perdata. Karena itu, kepentingan penggugat sebagai pemohon dan pemegang sita revindikasi, sita jaminan atau sita eksekusi, sita umum dalam pailit harus dikesampingkan demi melindungi kepentingan umum, dengan jalan menyita barang itu dalam perkara pidana, apabila barang yang bersangkutan memenuhi kategori yang dideskripsikan dalam Pasal 39 ayat (1) KUHAP. ${ }^{12}$

Apabila barang tersebut telah dilakukan sita perdata kemudian dilelang dan telah ditetapkan pemenangnya, namun ternyata barang tersebut harus disita pidana atas tindak pidana yang dilakukan oleh pemilik barang tersebut, maka salah satu upaya hukum yang dapat dilakukan oleh pemenang lelang adalah dengan mengajukan Praperadilan.

Pasal 1 butir 10 KUHAP memberikan pengertian mengenai Praperadilan, namun sehubungan dengan itu meskipun Pasal 77 ayat (1) huruf a KUHAP tidak menyebut secara tegas tentang penyitaan dan penggeledahan tetapi hanya menyebut penangkapan, penahanan dan penghentian penyidikan atau penuntutan, rincian ini tidak bersifat "limitatif". Ternyata Pasal 82 ayat (3) huruf d KUHAP memasukkan upaya paksa penyitaan ke dalam yurisdiksi substantif Praperadilan. Alasan lain yang mendukung tindakan penyitaan termasuk yurisdiksi Praperadilan berkenaan dengan penyitaan yang dilakukan terhadap barang pihak ketiga, dan barang itu tidak termasuk sebagai alat atau

\footnotetext{
${ }^{12}$ M. Yahya Harahap, Op.Cit. Hlm. 324

Pengelola: Program Studi Ilmu Hukum Universitas Muhammadiyah Jember

Penerbit: Universitas Muhammadiyah Jember
} 
Fairness and Justice: Jurnal Ilmiah Ilmu Hukum

p-ISSN: 1858-0106 e-ISSN: 2502-3926

Volume 17 Nomor 1 Mei 2019, Hlm 18-35

http://jurnal.unmuhjember.ac.id/index.php/FA

barang bukti. Dalam kasus yang seperti ini, pemilik barang harus diberi hak untuk mengajukan ketidakabsahan penyitaan kepada Praperadilan. ${ }^{13}$

Sehingga meskipun tidak diatur dalam PMK No. 27/PMK.06/2016 tentang apabila obyek lelang yang kemudian disita pidana, padahal pemenang lelang telah ditetapkan, maka pemenang lelang tersebut hanya dapat sebatas mengajukan upaya hukum melalui Praperadilan untuk mengetahui sah atau tidaknya penyitaan yang dilakukan terhadap barang lelang tersebut.

\subsubsection{Gugatan Perbuatan Melawan Hukum Kepada Pemilik Barang}

Mengenai ganti rugi ini juga berkaitan dengan perbuatan melawan hukum yang dilakukan oleh pemilik barang, dimana di dalam Pasal 1365 BW menyebutkan bahwa tiap perbuatan yang membawa kerugian kepada orang lain, mewajibkan orang yang menimbulkan kerugian tersebut karena kesalahannya untuk mengganti.

Pengadilan menetapkan pengertian luas untuk perbuatan melawan hukum, yaitu: ${ }^{14}$

a) Bertentangan dengan hak orang lain;

b) Bertentangan dengan kewajiban hukum si pelaku;

c) Melanggar kesusilaan; dan

d) Bertentangan dengan kepatutan, ketelitian dan kehati-hatian yang terdapat dalam masyarakat mengenai diri atau barang orang lain;

Pasal 1365 BW mensyaratkan adanya kesalahan, kesalahan dinyatakan sebagai pengertian umum yang mencakup kesengajaan maupun kelalaian. Pengertian kesalahan dalam Pasal 1365 BW menunjuk pada tanggungjawab atas suatu perbuatan yang bertentangan dengan hukum. Resiko dipakai sebagai lawan dari kesalahan. Pasal 1365 BW ini

${ }^{13}$ Ibid. Hlm. 8

${ }^{14}$ M. A. Moegni Djojodirdjo. Perbuatan Melawan Hukum Cet.2. 1982. Jakarta: Pradnya Paramita. Hlm. 35

Pengelola: Program Studi Ilmu Hukum Universitas Muhammadiyah Jember

Penerbit: Universitas Muhammadiyah Jember 
Fairness and Justice: Jurnal Ilmiah Ilmu Hukum

p-ISSN: 1858-0106 e-ISSN: 2502-3926

Volume 17 Nomor 1 Mei 2019, Hlm 18-35

http://jurnal.unmuhjember.ac.id/index.php/FA

menentukan kewajiban pelaku untuk membayar ganti rugi tetapi undangundang tidak mengatur lebih lanjut tentang ganti rugi yang disebabkan oleh perbuatan melawan hukum, hanya membatasi penggantian dalam bentuk kerugian tanpa menyebutkan istilah biaya dan bunga. ${ }^{15}$

Dengan mensyaratkan adanya kesalahan dalam Pasal 1365 BW, pembuat undang-undang hendak menekankan bahwa pelaku perbuatan melawan hukum harus bertanggungjawab atas kerugian yang ditimbulkannya bilamana perbuatan yang menimbulkan kerugian tersebut dapat dipersalahkan padanya. Dalam arti sempit, istilah schuld (kesalahan) hanya mencakup kesengajaan, sementara dalam arti luas mencakup kesengajaan dan kealpaan. ${ }^{16}$

Pengertian kerugian yang lebih luas dikemukakan oleh Mr. J. H. Nieuwenhuis sebagaimana yang diterjemahkan oleh Djasadin Saragih, pengertian kerugian adalah berkurangnya harta kekayaan pihak yang satu, yang disebabkan oleh perbuatan (melakukan atau membiarkan) yang melanggar norma oleh pihak yang lain. ${ }^{17}$ Yang dimaksud dengan pelanggaran norma oleh Nieuwenhuis adalah berupa wanprestasi dan perbuatan melanggar hukum.

Perbuatan melawan hukum yang menimbulkan kerugian dibatasi dan dibebankan kepada pihak yang melakukannya secara langsung, bukan kepada pihak yang telah membeli dengan prosedur sesuai dengan peraturan perundang-undangan dan dengan itikad baik, hal ini sesuai dengan Pasal 1341 ayat (2) BW yang melindungi hak-hak pihak ketiga yang telah diperolehnya dengan iktikad baik atas segala kebenadaan yang menjadi pokok perjanjian yang batal tersebut. Pembeli lelang adalah

15 Rahmat Setiawan. Tinjauan Elementer Perbuatan Melawan Hukum. 1982. Bandung: Alumni. Hlm. 44

${ }^{16}$ M. A. Moegni Djojodirdjo. Loc. Cit.

17 J.H. Nieuwenhuis, Pokok-Pokok Hukum Perikatan, terjemahan oleh Djasadin Saragiih, Airlangga University Press, Surabaya, 1985. Hlm. 54.

Pengelola: Program Studi Ilmu Hukum Universitas Muhammadiyah Jember

Penerbit: Universitas Muhammadiyah Jember 
Fairness and Justice: Jurnal Ilmiah Ilmu Hukum

p-ISSN: 1858-0106 e-ISSN: 2502-3926

Volume 17 Nomor 1 Mei 2019, Hlm 18-35

http://jurnal.unmuhjember.ac.id/index.php/FA

merupakan pihak ketiga dalam hubungan hukum antara kreditur dan debitur yang memperoleh hak kebendaan atas barang jaminan dalam penjualan umum. Maka adil jika seorang pembeli yang telah menyerahkan sejumlah uang, memperoleh hak atas barang yang bersangkutan. ${ }^{18}$

Sehingga apabila ada masalah terhadap barang lelang seperti barang tersebut disita pidana karena kesalahan dari pemilik barang, maka pembeli lelang dapat mengajukan tuntutan ganti rugi terhadap pemilik barang tersebut atas perbuatan melawan hukum, yang salah satunya untuk mengembalikan harga lelang yang telah dibayarkan beserta dengan ganti kerugian yang timbul dari proses lelang tersebut.

\subsubsection{Putusan Sita Pidana Atas Sita Perdata (Putusan Mahkamah Agung} No. 3233/K/Pdt./1995)

Maula Rahman (Kepala Bank BPD SULSEL) membeli sebidang tanah dari Abdul Rachman, yang kemudian diakui oleh Syech Alaudin sebagai tanahnya. Karena tidak terima, Syech Alaudin kemudian mengajukan gugatan dengan putusan bahwa tanah tersebut merupakan milik Syech Alaudin dan harus dikembalikan. Ketika perkara perdata berlangsung, Maula didakwa dengan tuduhan pidana korupsi yang mana harta dan aset-aset Maula disita dengan tujuan sebagai alat bukti, yang salah satunya adalah tanah yang disengketakan tersebut. Kemudian Syech Alaudin mengajukan permohonan untuk penetapan eksekusi terhadap tanah tersebut. Sehingga tanah yang disengketakan telah disita dua kali, yaitu sita jaminan (CB) karena adanya gugatan perdata yang diajukan oleh Syech Alaudin dan sita pidana sebagai barang bukti dalam perkara tindak pidana korupsi yang didakwakan kepada Maula. Hingga akhirnya putusan perkara tindak pidana korupsi tersebut menyatakan bahwa

\footnotetext{
${ }^{18}$ Purnama Tioria Siantur. Op.Cit. Hlm. 415.

Pengelola: Program Studi Ilmu Hukum Universitas Muhammadiyah Jember

Penerbit: Universitas Muhammadiyah Jember
} 
Fairness and Justice: Jurnal Ilmiah Ilmu Hukum

p-ISSN: 1858-0106 e-ISSN: 2502-3926

Volume 17 Nomor 1 Mei 2019, HIm 18-35

http://jurnal.unmuhjember.ac.id/index.php/FA

Maula bersalah melakukan kejahatan dan barang bukti berupa tanah tersebut dirampas untuk negara dan dikembalikan kepada Pemerintah Daerah Tk 1 Propinsi SULSEL. Dengan demikian, obyek sebidang tanah tersebut:

1. Menurut putusan perdata: merupakan Hak Miliknya Syech Alaudin dan Maula harus menyerahkan kepada Syech Alaudin;

2. Menurut putusan pidana: tanah tersbeut sebagai barang bukti tindak pidana korupsi dan dinyatakan untuk dirampas untuk Negara.

Kemudian dikarenakan adanya penetapan eksekusi yang diajukan oleh Syech Alaudin, Gubernur Tk. 1 SULSEL mengajukan gugatan perlawanan dimana putusan tingkat pertama dan kedua pengadilan menyatakan bahwa tanah merupakan milik Syech Alaudin dan perlawanan tersebut tidak dapat diterima. Namun pihak Gubernur yang tidak puas dengan putusan tersebut kemudian mengajukan kasasi ke Mahkamah Agung, yang pada akhirnya membatalkan putusan Pengadilan Tinggi dan menyatakan bahwa tanah yang disita pidana tersebut merupakan sah milik dari Gubernur Tk. 1 SULSEL.

Tanah yang menjadi sengketa tersebut hendaknya dilakukan penundaan eksekusi meskipun perkara perdatanya sudah mempunyai putusan yang berkekuatan hukum tetap, namun di sisi lain, proses pemeriksaan perkara pidananya masih berjalan dan tanah tersebut masih diperlukan sebagai alat bukti. Hal ini dikarenakan undang-undang telah menetapkan penyitaan pidana memiliki urgensi yang lebih tinggi dibanding dengan kepentingan individu di bidang perdata. Sesuai dengan Pasal 39 ayat (2) KUHAP bahwa benda yang berada dalam sitaan perdata dapat juga disita dalam perkara pidana asalkan barang yang dimaksud sesuai dengan ketentuan pada ayat (1).

Kemudian hasil dari putusan perkara pidana yaitu Terdakwa Maula terbukti bersalah dan tanah tersebut disita dan dirampas untuk negara, Pengelola: Program Studi Ilmu Hukum Universitas Muhammadiyah Jember Penerbit: Universitas Muhammadiyah Jember 
Fairness and Justice: Jurnal Ilmiah Ilmu Hukum

p-ISSN: 1858-0106 e-ISSN: 2502-3926

Volume 17 Nomor 1 Mei 2019, HIm 18-35

http://jurnal.unmuhjember.ac.id/index.php/FA

maka pihak manapun juga, termasuk Syech Alaudin tidak dapat lagi mendapatkan haknya untuk menguasai tanah tersebut meskipun ia telah mendapatkan penetapan eksekusi di dalam perkara perdata. Maka putusan yang diambil oleh Pengadilan Negeri maupun Pengadilan Tinggi atas perlawanan yang diajukan oleh pihak Gubernur, adalah tidak benar jika perlawanan tersebut ditolak dan tanah di kembalikan kepada pihak Syech Alaudin. Maka sudah benar jika Mahkamah Agung membatalkan putusan tersebut dan menyatakan bahwa tanah yang disita perdata dan pidana, tetap menjadi milik Pemerintah Daerah (dalam hal ini Gubernur).

Dalam putusan ini memang tidak berhubungan dengan lelang, namun putusan ini mencerminkan bahwa meskipun suatu barang telah disita perdata, kemudian barang tersebut harus disita pidana, maka sita pidana lah yang didahulukan prosesnya karena terkait dengan kepentingan orang banyak. Begitu pula jika terjadi dalam proses lelang. Apabila dalam prosesnya lelang telah dilakukan dan telah ditunjuk pemenangnya, dan pemenang tersebut telah membayar atas harga yang telah ditetapkan, namun kemudian obyek lelang disita dalam perkara pidana sebagai alat bukti atas tindak pidana yang dilakukan oleh pemiliknya, maka atas obyek lelang tersebut tidak dapat lagi dikuasai oleh siapapun, termasuk juga oleh pemenang lelang.

Kemudian, apabila dalam perkara pidana tersebut dikeluarkan putusan bahwa pemilik atas obyek lelang terbukti bersalah dan obyek lelang yang disita tersebut akhirnya harus dirampas untuk negara, maka pemenang lelang tidak akan bisa mengajukan perlawanan atas putusan tersebut. Mereka hanya bisa melakukan upaya hukum dalam mengajukan Praperadilan untuk membuktikan apakah penyitaan benar dilakukan terhadap obyek lelang tersebut. Jika Praperadilan memutuskan bahwa penyitaan sudah dilakukan dengan benar, maka upaya hukum yang 
Fairness and Justice: Jurnal Ilmiah Ilmu Hukum

p-ISSN: 1858-0106 e-ISSN: 2502-3926

Volume 17 Nomor 1 Mei 2019, Hlm 18-35

http://jurnal.unmuhjember.ac.id/index.php/FA

dapat dilakukan oleh pemenang lelang adalah menuntut ganti kerugian terhadap pemilik barang tersebut.

Namun sayangnya, baik di dalam peraturan ataupun dalam putusan diatas, tidak ada perlindungan hukum untuk pihak (pemenang lelang) yang merasa dirugikan atas perkara tersebut. Maka sudah seharusnya jika pihak (pemenang lelang) yang merasa dirugikan dilindungi dengan aturan-aturan hukum agar pihak tersebut masih bisa mendapatkan hak nya atas barang yang menjadi sengketa. Hal ini juga berkaitan dengan pembeli yang telah beritikad baik dalam proses pelaksanaan lelang.

\section{Kesimpulan}

Berdasarkan uraian pembahasan yang telah disampaikan di dalam bab sebelumnya pada artikel ini, dapat ditarik beberapa kesimpulan. Beberapa kesimpulan tersebut yakni sebagai berikut:

1. Peserta lelang yang telah ditetapkan sebagai pemenang dan sudah melakukan pembayaran atas harga yang telah ditetapkan, namun kemudian obyek lelang tersebut harus dilakukan penyitaan secara pidana karena pemilik awalnya telah melakukan tindak pidana yang memungkinkan semua harta kekayaannya harus disita, padahal pemenang lelang sudah beritikad baik dalam pelaksanaan lelang, masih belum mendapatkan kepastian hukum atas tidak terpenuhinya hak atas pembeli lelang yaitu yang seharusnya benda atau objek lelang tersebut bebas dari tuntutan pihak manapun sehingga pemenang lelang dapat menguasai barang tersebut secara penuh/absolut.

2. Upaya hukum yang dapat dilakukan oleh pemenang lelang yang merasa dirugikan atas obyek lelang yang disita pidana adalah mengajukan Praperadilan, untuk mengetahui sah atau tidaknya penyitaan yang dilakukan terhadap obyek lelang. Jika Praperadilan Pengelola: Program Studi Ilmu Hukum Universitas Muhammadiyah Jember 
Fairness and Justice: Jurnal Ilmiah Ilmu Hukum

p-ISSN: 1858-0106 e-ISSN: 2502-3926

Volume 17 Nomor 1 Mei 2019, HIm 18-35

http://jurnal.unmuhjember.ac.id/index.php/FA

memutuskan bahwa penyitaan tersebut tidak sah, maka pemenang lelang dapat menguasai kembali barang tersebut. Namun apabila penyitaan atas barang tersebut adalah sah, maka pemenang lelang dapat menuntut ganti kerugian (atas perbuatan melawan hukum ) kepada pemilik barang dengan pengembalian harga lelang dan ditambah dengan kerugian yang dialami oleh pemenang lelang. 
Fairness and Justice: Jurnal Ilmiah Ilmu Hukum

p-ISSN: 1858-0106 e-ISSN: 2502-3926

Volume 17 Nomor 1 Mei 2019, HIm 18-35

http://jurnal.unmuhjember.ac.id/index.php/FA

\section{Daftar Pustaka}

\section{$\underline{\text { Buku }}$}

Afiah, Ratna Nurul. (1989). Barang Bukti Dalam Proses Pidana. Jakarta: Sinar Grafika

Agustina, Rosa. (2003). Perbuatan Melawan Hukum. Jakarta: Universitas Indonesia

Djojodirdjo, M. A. Moegni. (1982). Perbuatan Melawan Hukum Cet.2. Jakarta: Pradnya Paramita

Harahap, M. Yahya. (2009). Hukum Acara Perdata tentang Gugatan, Persidangan, Penyitaan, Pembuktian dan Putusan Pengadilan. Jakarta: Sinar Grafika (2016). Pembahasan Permasalahan dan Penerapan

KUHAP Pemeriksaan Sidang Pengadilan, Banding, Kasasi dan Peninjauan Kembali. Jakarta: Sinar Grafika

Marpaung, Leden. (2009). Proses Penanganan Perkara Pidana (Penyelidikan dan Penyidikan). Jakarta: Sinar Grafika

Marzuki, Peter Mahmud. (2014). Penelitian Hukum (Edisi Revisi). Jakarta: Prenadamedia Group

Nieuwenhuis, J.H. (1985). Pokok-Pokok Hukum Perikatan (terjemahan oleh Djasadin Saragih), Surabaya: Airlangga University Press

Santoso, Urip. (2015). Pendaftaran dan Peralihan Hak Atas Tanah. Jakarta: Prenadamedia Group

Setiawan, Rahmat. (1982). Tinjauan Elementer Perbuatan Melawan Hukum. Bandung: Alumni

Siantura, Purnama Tiora. (2013). Perlindungan Hukum Terhadap Pembeli Barang Jaminan Tidak Bergerak Melalui Lelang. Bandung: CV. Mandar Maju

Simanjuntak, Nikolas. (2009). Acara Pidana Indonesia Dalam Sirkus Hukum.

Bogor: Ghalia Indonesia

Pengelola: Program Studi Ilmu Hukum Universitas Muhammadiyah Jember

Penerbit: Universitas Muhammadiyah Jember 
Fairness and Justice: Jurnal Ilmiah Ilmu Hukum

p-ISSN: 1858-0106 e-ISSN: 2502-3926

Volume 17 Nomor 1 Mei 2019, HIm 18-35

http://jurnal.unmuhjember.ac.id/index.php/FA

Soemitro, Rochmat. (1987). Peraturan dan Instruksi Lelang. Bandung: PT. Eresco

Usman, Rachmadi. (2016). Hukum Lelang. Jakarta: Sinar Grafika

\section{Jurnal}

Dwi Putro, Widodo. Penjelasan Hukum Pembeli Beritikad Baik. Judicial Sector Program.

\section{Tesis atau Disertasi}

Faisal, Muhammad. (2014). Upaya Perlindungan Hukum Pemenang Lelang Sebagai Pembeli Beritikad Baik Terhadap Putusan Re-Eksekusi. Jurnal Hukum dan Pembangunan Tahun ke-44 No.1 Januari-Maret. 2014;

Sidi Alkahfi Setiawan. (2013). Perlindungan Hukum Pekerja Pemegang Saham Di PT Bank Central Asia Tbk. Fakultas Hukum Universitas Jember.

Palgunardi, Prasetya. Diktat Perkuliahan Hukum Lelang Universitas Airlangga.

Subhan, M. Hadi. Diktat Perkuliahan Hukum Lelang Universitas Airlangga. 